\title{
Decreased Protein Kinase C Expression in the Cochlear Fibroblasts of Diabetic Rat Models Induced by Curcumin
}

\author{
Kurkumin Tarafından Indüklenen Diyabetik Sıçan Modellerinin Koklear \\ Fibroblastlarındaki Azalmış Protein Kinaz C Ekspresyonları
}

\author{
(D) Tengku Siti Hajar HARYUNA*, (D) Farhat FARHAT, (D) Siska INDRIANY \\ Universitas Sumatera Utara, Faculty of Medicine, Department of Otorhinolaryngology-Head and Neck Surgery, Medan, Indonesia
}

\begin{abstract}
Objectives: Microcirculation and hemodynamic disturbances, including in the cochlea, are commonly found in diabetic patients. A study on diabetic rats discovered histopathological changes in outer hair cells and the spiral ganglion and mitochondrial damage in the ear. Hyperglycemia can increase the activation of protein kinase $\mathrm{C}$ (PKC). Curcumin as an antioxidant also affects the regulation of $\mathrm{PKC}$ and $\mathrm{Ca}^{2+}$. The aim of this study was to determine the role of curcumin in decreasing PKC expression in the cochlear fibroblasts of diabetic rats.

Materials and Methods: An experimental study was performed on 24 Wistar rats divided into the following 6 groups: group 1: control group; group 2: diabetic group without curcumin administration; groups 3 and 4: diabetic groups with curcumin administration ( $200 \mathrm{mg} / \mathrm{kg}$ and $400 \mathrm{mg} / \mathrm{kg}$ for 3 days, respectively); groups 5 and 6: diabetic groups with curcumin administration ( $200 \mathrm{mg} / \mathrm{kg}$ and $400 \mathrm{mg} / \mathrm{kg}$ for 8 days, respectively). Cochlear tissues were taken from all groups and immunohistochemistry-stained, and the PKC expression scores were analyzed with one-way ANOVA (a significance level of 0.05 ).

Results: Significant differences in PKC expression ( $p<0.05$ ) were found between group 1 and group 2, and group 2 and groups 3, 4, 5, and 6. There was no significant difference in PKC expression regarding the different doses and the duration of curcumin administration.

Conclusion: Curcumin can reduce PKC expression in the cochlear fibroblasts of diabetic rats.

Key words: Diabetes mellitus, curcumin, fibroblast, cochlea, protein kinase C
\end{abstract}

öz

Amaç: Kokleada dahil olmak üzere mikrodolaşım ve hemodinamik bozukluklar, diyabetli hastalarda yaygın olarak görülür. Diyabetik sıçanlar üzerine yapılan bir çalıșma, dıștaki saç hücrelerindeki histopatolojik değişiklikleri, sarmal gangliyon ve kulaktaki mitokondriyal hasarı ortaya koymuştur. Hiperglisemi, protein kinaz C (PKC) aktivasyonunu artırabilir. Bir antioksidan olan kurkumin, PKC ve $\mathrm{Ca}^{2+}$ düzenini de etkiler. Bu çalışmanın amacı, diyabetik sıçanlarda koklear fibroblastlarda PKC ekspresyonlarının azaltılmasında kurkuminin rolünü öğrenmektir.

Gereç ve Yöntemler: Yirmi dört adet Wistar sıçan 6 gruba ayrılmıştır. Grup 1: kontrol grubu; grup 2: kurkumin uygulanmayan diyabetik grup; grup 3 ve 4: kurkumin uygulanan diyabetik gruplar (sırasıyla 3 gün süreyle $200 \mathrm{mg} / \mathrm{kg}$ ve $400 \mathrm{mg} / \mathrm{kg}$ ); grup 5 ve 6: kurkumin uygulaması olan diyabetik gruplar (sırasıyla 8 gün boyunca $200 \mathrm{mg} / \mathrm{kg}$ ve $400 \mathrm{mg} / \mathrm{kg}$ ). Koklear dokular tüm gruplardan alındı ve immünohistokimyasal olarak boyandı ve PKC ekspresyon skorları, tek-yönlü ANOVA (0.05'lik önem derecesi) ile analiz edildi.

Bulgular: Grup 1 ile grup 2, grup 2 ve grup 3, 4, 5, 6 arasında PKC ekspresyonlarında önemli farklılıklar bulundu ( $p<0.05$ ). Farklı dozlar ve kurkuminin uygulama süresi ile ilgili olarak PKC ekspresyonunda önemli bir fark yoktu.

Sonuç: Kurkumin, diyabetik sıçanların koklear fibroblastlarındaki PKC ekspresyonlarını azaltabilir.

Anahtar kelimeler: Şeker hastalığı, kurkumin, fibroblast, koklea, protein kinaz C

*Correspondence: E-mail: tengkusitihajarharyuna@gmail.com, Phone: +628126061694 ORCID-ID: orcid.org/0000-0003-2779-3285

Received: 03.10.2017, Accepted: 08.02.2018

-Turk J Pharm Sci, Published by Galenos Publishing House. 


\section{INTRODUCTION}

Diabetes mellitus (DM) is a chronic disease caused by inadequate production of insulin or ineffective usage of the provided insulin, marked by an increase in blood glucose (hyperglycemia), and found as an inherited disease. It is estimated that there will be 300 million diabetic patients worldwide in 2025 .

Diabetes has the potential to cause various complications due to angiopathy and neuropathy. There have been several studies over the years about the relationship between DM and hearing loss. Disturbances in microcirculation and hemodynamic changes (including in the cochlea) are often found in diabetic patients. Further research on experimental animals such as diabetic rats has reported pathological changes in outer hair cells and the spiral ganglion and mitochondrial damage. ${ }^{2}$

A similar result can also be found in a study conducted by Lee et al., ${ }^{3}$ which found histologic abnormalities, such as degeneration of the organ of Corti and spiral ganglion cells, related to hyperglycemia and obesity.

Several biochemical pathways have also been studied to discover the effect of hyperglycemia, such as the diacylglycerol (DAG) activation pathway, protein kinase $C$ (PKC) activation, increased polyol, increased oxidative stress, and overproduction of advanced glycation end products. These biochemical pathways are strongly related to reactive oxygen species (ROS), leading to vascular damage. ${ }^{4,5}$

Some existing hypotheses explain the harmful side effects of hyperglycemia; one of them is the constant activation of PKC. PKC has been linked to vascular changes, such as increased permeability, contractility, extracellular matrix synthesis, cell growth and apoptosis, angiogenesis, cytokines activity, and inhibition. ${ }^{6}$

Curcumin is an active, yellow component of turmeric, isolated from the plant Curcuma longa. This molecule has a therapeutic effect on various diseases, especially anti-inflammatory, antimicrobial, and antioxidant. It has been reported that curcumin is a bifunctional antioxidant possessing direct and indirect antioxidant activity by scavenging ROS and neutralizing them and inducting upregulation of various cytoprotective proteins and antioxidants such superoxide dismutase, catalase, and glutathione peroxidase. The presence of phenolic $\mathrm{OH}$ and $\mathrm{CH}_{2}$ groups in the $\beta$-diketone part of this natural compound significantly contributes to its potent antioxidant property. ${ }^{7-9}$

Curcumin affects PKC and $\mathrm{Ca}^{2+}$ regulation. The effect of inhibited ROS caused by curcumin depends on the curcumin dose through its effect on $\mathrm{PKC}$ activity and $\mathrm{Ca}^{2+}$ regulation. ${ }^{10}$

The role of curcumin in the treatment and prevention of hearing loss through its inhibitory mechanism towards PKC in the cochlear fibroblasts of diabetic rats (Rattus norvegicus) has never been studied, and so the objective of the present study was to demonstrate the role of curcumin in reducing PKC expression in the cochlear fibroblasts of diabetic rats.

\section{MATERIALS AND METHODS}

\section{Animal subjects}

This study was an experimental study with a randomized posttest-only control group design using Wistar rats $(R$. norvegicus) that were male, healthy, and average weight $200 \mathrm{~g}$. The 24 rats were divided into 6 groups, with 4 rats in each group. The rats were obtained from the Laboratory of Biochemistry, Faculty of Medicine, Universitas Airlangga, Surabaya, Indonesia.

To ensure that all the procedures were ethically acceptable, a proposal was submitted to the Research Ethics Committee. This study earned approval from the Health Research Ethics Committee of Universitas Sumatera Utara, Indonesia, no. 433/ KOMET/FKUSU/2015.

\section{Treatments}

In the study, after the white rats had adapted to the cage environment in the laboratory for 2 weeks, they were treated according to the plan.

Group 1 (control group) was injected with a single dose of sodium citrate, obtained from $1.47 \mathrm{~g}$ of sodium citrate solution in $50 \mathrm{~mL}$ of $\mathrm{dH}_{2} \mathrm{O}$ intraperitoneally on the $1^{\text {st }}$ day, and then terminated on the $5^{\text {th }}$ day.

Group 2 was injected with a single dose of streptozotocin (STZ) (Bioworld, USA) $60 \mathrm{mg} / \mathrm{kgbw}$, and then terminated on the $5^{\text {th }}$ day.

Group 3 was injected with a single dose of STZ $60 \mathrm{mg} / \mathrm{kgbw}$ followed by curcumin $200 \mathrm{mg} / \mathrm{kgbw} /$ day orally for 3 days and terminated on the $5^{\text {th }}$ day.

Group 4 was injected with a single dose of STZ $60 \mathrm{mg} / \mathrm{kgbw}$ followed by curcumin $400 \mathrm{mg} / \mathrm{kgbw} /$ day orally for 3 days and terminated on the $5^{\text {th }}$ day.

Group 5 was injected with a single dose of STZ $60 \mathrm{mg} / \mathrm{kkgbw}$ followed by curcumin $200 \mathrm{mg} / \mathrm{kgbw} /$ day orally for 8 days and terminated on the $10^{\text {th }}$ day.

Group 6 was injected with a single dose of STZ $60 \mathrm{mg} / \mathrm{kgbw}$ followed by curcumin $400 \mathrm{mg} / \mathrm{kgbw} /$ day orally for 8 days and terminated on the $10^{\text {th }}$ day.

\section{Procedures}

\section{STZ-induced diabetes}

The rats were fasted for $4 \mathrm{~h}$ to empty the stomach and decrease the risk of aspiration. Induction was performed on the rats by injecting STZ solution $60 \mathrm{mg} / \mathrm{kgbw}^{11}$ intraperitoneally with the required doses mentioned above (diabetic groups: groups 2-6). In order to avoid sudden postinjection hypoglycemia, the rats were given sucrose $10 \%$ or dextrose $10 \%$ solution throughout the $1^{\text {st }}$ night. Every morning, the fasting blood sugar levels of the rats were examined with an Advance Glucometer (Boehringer Mannheim, Germany) by taking blood from the peripheral blood vessel in the tail. Hyperglycemia is diagnosed when the blood sugar level is $>200 \mathrm{mg} / \mathrm{dL}$ after $48 \mathrm{~h}$ of STZ induction..$^{2}$ If the blood sugar is $<200 \mathrm{mg} / \mathrm{dL}$ then the rats are eliminated from the sample. 
After being diagnosed as hyperglycemic, the rats were given curcumin according to the required dose per group and they were terminated after the procedure.

\section{Procedure of curcumin administration}

Powdered curcumin was used at the level of $16.62 \pm 0.14 \% \mathrm{~b} / \mathrm{b}$ using thin layer chromatography - densitometry. The given preparation included powdered curcumin at a dose of 200 $\mathrm{mg} / \mathrm{kgbw} /$ day and $400 \mathrm{mg} / \mathrm{kgbw} /$ day per rat suspended in carboxymethyl cellulose $0.5 \%$ and administered orally into the stomach of the rat via a nasogastric tube.

\section{Procedure of rat cochlear tissue collection}

Termination was conducted on rats in all groups by temporal bone necropsy. The tissue sample taken was fixated with buffered formalin solution $10 \%$ and decalcified with EDTA for 4 weeks. Each tissue sample was prepared in paraffin blocks and sliced into 4- $\mu \mathrm{m}$-thick sections and placed inside the glass object and then stained with hematoxylin-eosin and immunohistochemical staining of PKC was performed with polyclonal anti-PKC antibody (catalogue\#: ENT3752, Elabscience).

\section{Cell-counting method}

All slides were examined using an Olympus XC 10 microscope (under 40x magnification) by two anatomical pathologists separately with the double-blind method. PKC expression scores were evaluated by multiplying the area score $(0=0 \%$, $1=\langle 10 \%, 2=10 \%-50 \%, 3=\rangle 50 \%)$ by the intensity score $(0,1,2$, or 3$)^{13}$

\section{Statistical analysis}

To analyze the mean differences between more than two groups, one-way ANOVA was used (a significance level of 0.05). Before one-way ANOVA, we used the Shapiro-Wilk test to prove that the data were normally distributed and post-hoc tests to see the differences of groups.

\section{RESULTS}

Mean differences in PKC expression were seen in all groups. The lowest PKC expression was found in the control group and the highest PKC expression was found in the diabetic group without curcumin administration (Chart 1).

It is also shown in Chart 1 that the diabetic groups administered curcumin (groups 3-6) had lower mean values of PKC expression compared to the diabetic group not administered curcumin (group 2).

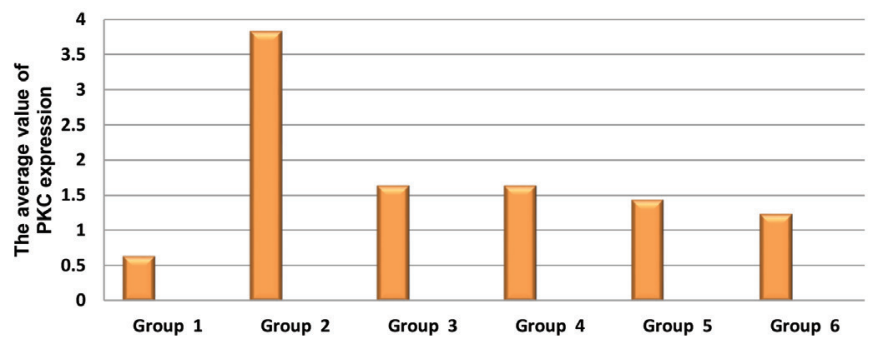

Chart 1. The average value of PKC expression in the cochlear lateral fibroblast wall of all groups

PKC: Protein kinase $\mathrm{C}$
In order to get a proper and detailed view of the cochlear tissue histopathologically, hematoxylin-eosin staining was performed and used as a comparison for further immunohistochemical staining (Figure 1).

Clinical test results of curcumin in decreasing PKC expression in the cochlear fibroblasts of diabetic rats can be seen in Figure 2.

The fibroblasts in the diabetic group (group 2) showed higher density compared to the other groups, whereas the fibroblasts within the diabetic group administered curcumin (groups 3-6) showed lower density.

The results obtained from the histopathological examination above were then processed and analyzed statistically to find

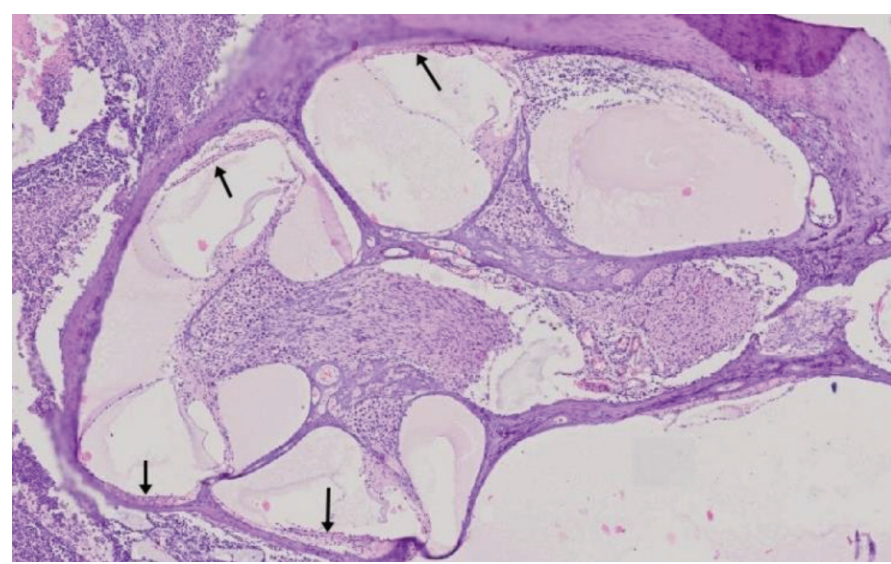

Figure 1. The cochlear lateral wall section of Rattus norvegicus (black arrow) with hematoxylin-eosin staining (under $40 \times$ magnification)

Table 1. The ANOVA test results in various groups

\begin{tabular}{|c|c|c|c|}
\hline \multirow{2}{*}{ Groups } & & \multicolumn{2}{|c|}{ PKC expression } \\
\hline & & Mean \pm SD & $\mathrm{p}$ value \\
\hline \multirow{5}{*}{ Group 1} & Group 2 & $-3.2 \pm 0.374$ & $0.000 *$ \\
\hline & Group 3 & $-1.0 \pm 0.374$ & 0.200 \\
\hline & Group 4 & $-1.0 \pm 0.374$ & 0.200 \\
\hline & Group 5 & $-0.8 \pm 0.374$ & 0.643 \\
\hline & Group 6 & $-0.6 \pm 0.374$ & 1.000 \\
\hline \multirow{4}{*}{ Group 2} & Group 3 & $2.2 \pm 0.374$ & $0.000^{*}$ \\
\hline & Group 4 & $2.2 \pm 0.374$ & $0.000 *$ \\
\hline & Group 5 & $2.4 \pm 0.374$ & $0.000^{*}$ \\
\hline & Group 6 & $2.6 \pm 0.374$ & $0.000^{*}$ \\
\hline \multirow{3}{*}{ Group 3} & Group 4 & $0 \pm 0.374$ & 1.000 \\
\hline & Group 5 & $0.2 \pm 0.374$ & 1.000 \\
\hline & Group 6 & $0.4 \pm 0.374$ & 1.000 \\
\hline \multirow{2}{*}{ Group 4} & Group 5 & $0.2 \pm 0.374$ & 1.000 \\
\hline & Group 6 & $0.4 \pm 0.374$ & 1.000 \\
\hline Group 5 & Group 6 & $0.2 \pm 0.374$ & 1.000 \\
\hline
\end{tabular}

*statistically significant, PKC: Protein kinase C, SD: Standard deviation 


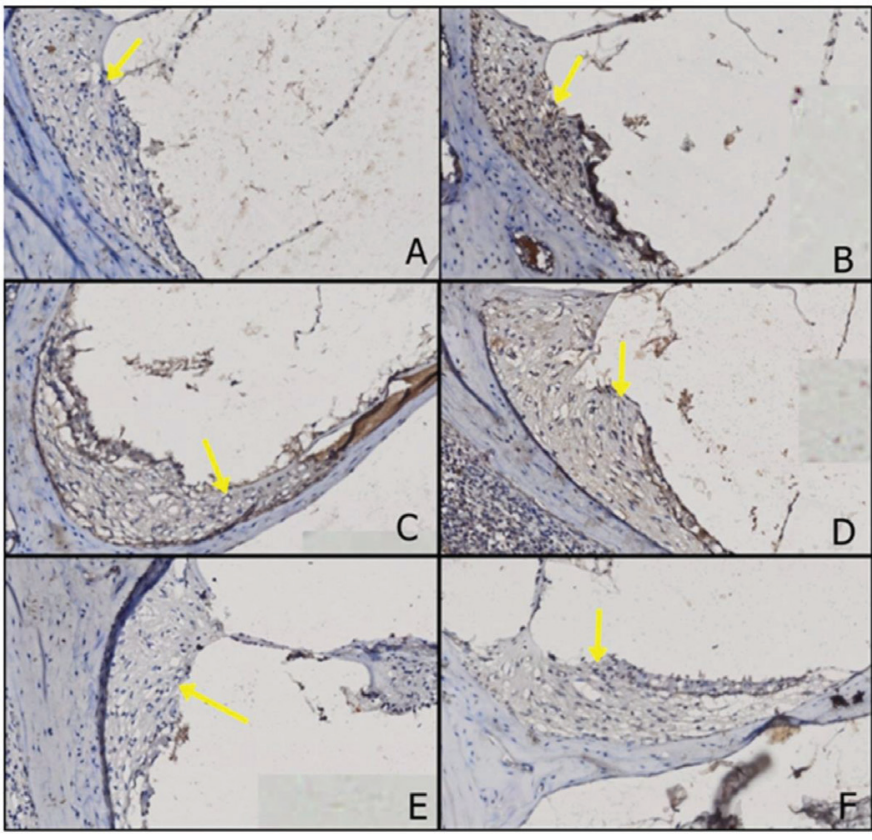

Figure 2. The expressions of PKC in each group (under 100x magnification): a) Group 1; b) Group 2; c) Group 3; d) Group 4; e) Group 5; f) Group 6. The yellow arrow indicates the expressions of PKC in cochlear fibroblasts marked by brown stains

PKC: Protein kinase $C$

the differences between each group and the interpreted results are shown in Table 1.

According to Table 1, there was a statistically significant difference $(p<0.05)$ in the mean value of PKC expression between group 1 and the diabetic group not administered curcumin (group 2).

As shown in Table 1, the administration of curcumin in the diabetic groups (groups 3-6) decreased PKC expression significantly $(p<0.05)$ compared to the diabetic group not administered curcumin (group 2).

According to Table 1, the different doses (200 and 400 mg/ $\mathrm{kgbw} /$ day) and the duration of curcumin administration ( 3 and 8 days) showed no statistically significant differences ( $p>0.05$ ) in PKC expression.

\section{DISCUSSION}

Sensorineural hearing loss in diabetic patients is caused by cochlear angiopathy characterized by dilatation of the blood vessels of the stria vascularis, atrophy, and loss of outer hair cells. Research on diabetic rats found that microangiopathy occurs inside the inner ear and thickening of basement membranes of capillaries in the stria vascularis. ${ }^{14,15}$

To help identify the gene that plays a role in the human auditory system, rats were used as the experimental animal since they are genetically similar to humans $(>70 \%){ }^{16}$ The objective of this study was to determine the role of curcumin in decreasing PKC expression in the cochlear fibroblasts of diabetic rats $(R$. norvegicus).
Earlier studies have not proved any effect of curcumin on PKC expression in the lateral wall of cochlear fibroblasts in diabetic model rats. This study is the first to prove that curcumin is able to decrease the expression of PKC in the lateral wall of cochlear fibroblasts in these rats.

The dose of curcumin used in this study was $200 \mathrm{mg} / \mathrm{kgbw}$ according to the previous study, in which that dose of curcumin acted as an antioxidant ${ }^{17}$ due to its inhibitory effect on ROS by affecting the PKC pathway and calcium regulation. ${ }^{10}$ In order to find the optimal dose and duration of curcumin administration to decrease PKC expression, we compared the doses of 200 $\mathrm{mg} / \mathrm{kgbw} /$ day and $400 \mathrm{mg} / \mathrm{kgbw} /$ day with the durations of administration of 3 and 8 days. In regard to the present study, curcumin is a compound that functions dependently on the dose and duration of administration. Thus, the dose and duration of administration can affect gene expression. ${ }^{18}$

A significant difference in the mean value of PKC expression between the control group and the diabetic group not administered curcumin was found in this study. Curcumin as an antioxidant can inhibit ROS via the PKC pathway and calcium regulation. ${ }^{10}$ This discovery strengthens the presumption that hyperglycemia will cause cellular dysfunction that activates PKC persistently and stimulates the continuous synthesis of endogenous ROS, leading to cell damage, including cochlear fibroblasts.

In the present study, there were differences in the mean values of PKC expression in all groups. The lowest PKC expression was found in group 1 and the highest PKC expression was found in group 2.

Chronic hyperglycemia can cause various cellular reactions that play a role in the pathomechanism of various complications, caused by cell dysfunction and damage. The cellular reactions caused by chronic hyperglycemia are nonenzymatic glycation, activation of the signal transduction pathway increasing DAG synthesis, increased ROS synthesis as the waste product of energy catabolism leading to cell and tissue oxidative stress, and activation of aldolase reductase. ${ }^{19}$ In DM, increased ROS production also occurs via several mechanisms, such as polyol pathway, increased AGEs production, excessive radical superoxide production, and PKC activation. The increased PKC activity may also result in increased ROS production. ${ }^{20}$

The increased DAG synthesis in hyperglycemia via the signal transduction pathway, especially that coming from the transformation of glucose into glycerol 3-phosphate, may lead to increased DAG synthesis de novo. DAG is partially synthesized from phosphatidylcholine and phosphatidylinositol of the "insulin-sensitive" cell membrane continuously. The perpetual DAG synthesis and the potentiation effect from the free fatty acid in the blood may initiate the PKC activation pathway persistently, leading to cellular response via the modification of various proteins controlling signal transduction and cytokine expression. 19,21,22

The modification of transcription factor and cell cycle may cause cell dysfunction and damage due to the disturbance in cell proliferation and differentiation as well as the abnormality in 
apoptosis. Additionally, the modification of transcription factor and postprotein translation can also stimulate the synthesis of endogenous ROS, resulting in cell damage. ${ }^{19}$

Thereby, in the STZ-induced diabetes group, PKC expression was increased due to the continuous activation of the PKC pathway.

In the present study, groups 3, 4, 5, and 6 (diabetic groups administered curcumin) showed lower mean values of PKC expression compared to group 2 (diabetic group not administered curcumin). The decreased mean values of PKC expression in the STZ-induced diabetes groups receiving curcumin was due to the activity of curcumin, which can eliminate the formation of ROS, thereby inhibiting PKC activation at the cellular level.

A similar study conducted by $\mathrm{KaO}$ et al. ${ }^{23}$ found significant inhibition in PKC expression in patients with hepatocellular carcinoma (Hep 3B cell) treated by curcumin. The decreased expression mechanism of PKC is not fully understood, but many previous in vivo and in vitro studies have shown a strong indication of decreased expression of PKC caused by curcumin acting as a noncompetitive and selective inhibitor of phosphorylase kinase.

Phosphorylase kinase is the key enzyme in glycogen metabolism; if this enzyme is inhibited then autocrine effect as cell growth factor is also inhibited, which affects the cell proliferation disturbance. Curcumin is also a potent antioxidant to neutralize ROS and inhibit lipid peroxidation. ${ }^{24}$

Similarly, the study carried out by Jancinova et al. ${ }^{25}$ observed that curcumin can inhibit PKC in the neutrophils of Lewis rats suffering from arthritis in vitro or experimentally.

Another study demonstrated that curcumin can serve as an antioxidant by eliminating phorbol-12, myristate-13 acetate to inhibit ROS. This inhibitory pattern shows that curcumin mechanically inhibits PKC and calcium regulation. ${ }^{10}$

The antioxidant activity of curcumin is based on the phenolic group in it through donation of a hydrogen atom. Moreover, the phenolic group plays a key role for the activity of free radicals scavenging. ${ }^{26}$

In the present study, the different doses of curcumin, $200 \mathrm{mg} /$ $\mathrm{kgbw} /$ day and $400 \mathrm{mg} / \mathrm{kgbw} /$ day, with duration of 3 and 8 days showed no statistically significant differences ( $p>0.05$ ) in PKC expression. Nevertheless, the administration of a higher dose of curcumin with a longer duration (group 6) demonstrated more decreased PKC expression compared to a lower dose of curcumin with a shorter duration (group 3).

\section{CONCLUSIONS}

According to this study, we conclude that curcumin is an antioxidant that mechanically inhibits PKC expression in the cochlear fibroblasts of diabetic rats administered curcumin of either $200 \mathrm{mg} / \mathrm{kgbw} / \mathrm{day}$ or $400 \mathrm{mg} / \mathrm{kgbw} /$ day for 3 days or 8 days. Curcumin is considered a therapeutic agent that is effective in repairing fibroblast damage in the cochlear lateral wall caused by DM, which was determined through the expression of PKC. This study can act as basic scientific research in traditional therapy to manage hearing loss caused by $D M$ in the future.

\section{ACKNOWLEDGEMENTS}

This study was supported by DIPA Direktorat Penelitian dan Pengabdian kepada Masyarakat, Universitas Sumatera Utara 2015.

Conflict of Interest: No conflict of interest was declared by the authors.

\section{REFERENCES}

1. Malucelli DA, Malucelli FJ, Fonseca VR, Zeigeboim B, Ribas A, Trotta FD, Silva TP. Hearing loss prevalence in patients with diabetes mellitus type 1. Braz J Otorhinolaryngol. 2012;78:105-115.

2. Xipeng L, Ruiyu L, Meng L, Yanzhuo Z, Kaosan G, Liping W. Effect of Diabetes on Hearing and Cochlear Structures. J Otology. 2013;8:82-87.

3. Lee HS, Kim KR, Chung WH, Cho YS, Hong SH. Early Sensorineural Hearing Loss in Ob/Ob Mouse, an Animal Model of Type 2 Diabetes. Clin Exp Otorhinolaryngol. 2008;1:211-216.

4. Noh $\mathrm{H}$, King GL. The role of protein kinase $\mathrm{C}$ activation in diabetic nephropathy. Kidney Int Suppl. 2007;72:49-53.

5. Aronson D. Hyperglycemia and the pathobiology of diabetic complications. 2nd ed. Fisman EZ, Tenenbaum A. Cardiovascular Diabetology: Clinical, Metabolic and Inflammatory Facets. Adv Cardiol. 2008;1:16.

6. Geraldes P, King GL. Activation of Protein Kinase C Isoform and Its Impact on Diabetic Complications. Circ Res. 2010;106:1319-1331.

7. Correa F, Buelna-Chontal M, Hernández-Reséndiz S, García-Niño WR, Roldán FJ, Soto V, Silva-Palacios A, Amador A, Pedraza-Chaverrí J, Tapia E, Zazueta C. Curcumin maintains cardiac and mitochondrial function in chronic kidney disease. Free Radic Biol Med. 2013;61:119-129.

8. Trujillo J, Chirino YI, Molina-Jijón E, Andérica-Romero AC, Tapia E, Pedraza-Chaverrí J. Renoprotective effect of the antioxidant curcumin: Recent Findings. Redox Biol. 2013;1:448-456.

9. Yadav SK, Sah AK, Jha RK, Sah P, Shah DK. Turmeric (curcumin) remedies gastroprotective action. Pharmacogn Rev. 2013;7:42-46.

10. Balasubramanyam M, Koteswari AA, Kumar RS, Monickaraj SF, Maheswari JU, Mohan V. Curcumin-induced inhibition of cellular reactive oxygen species generation: Novel therapeutic implications. J Biosci. 2003;28:715-721.

11. Ragbetli C, Ebubekir C. Effect of Streptozotocin on Biochmical Parameters in Rats. Asian J Chem. 2010;22:2376-2378.

12. Wongeakin N, Sridulyakul P, Jariyapongskul A, Suksamrarn A, Patumraj $\mathrm{S}$. Effects of curcumin and tetrahydrocurcumin on diabetes induced endothelial dysfunction. Afr J Biochem Res. 2009;3:259-265.

13. Tan KB, Putti TC. Cyclooxigenase 2 expression in nasopharyngeal carcinoma: immunohistochemical findings and potential implication. J Clin Pathol. 2005;5:535-538.

14. Austin DF, Konrad-Martin D, Griest S, McMillan GP, McDermott D, Fausti S. Diabetes-Related Change in Hearing. Laryngoscope. 2009;119:17881796.

15. Maia CA, Campos CA. Diabetes Mellitus as etiological factor of hearing loss. Braz J Ottorinolaringol. 2005;71:208-214. 
16. Gravel JS, Ruben RJ. Auditory Deprivation and Its Consequences: From Animal Models to Human. In: Van De Water TR, Popper AN, Fay RR, eds. Clinical Aspect of Hearing. New York; Springer; 1996:86-92.

17. González-Salazar A, Molina-Jijón E, Correa F, Zarco-Márquez G, Calderón-Oliver M, Tapia E, Zazueta C, Pedraza-Chaverri J. Curcumin Protects from Cardiac Reperfusion Damage by Attenuation of Oxidant Stress and Mitochondrial Dysfunction. Cardiovasc Toxicol. 2011;11:357364.

18. Van Erk MJ, Teuling E, Staal YC, Huybers S, Van Bladeren PJ, Aarts JM, Van Ommen B. Time-and dose-dependent effects of curcumin on gene expression in human colon cancer cells. J Carcinog. 2004;3:8.

19. Koya D, King GL. Protein Kinase C Activation and the Development of Diabetic Complications. Diabetes. 1998;47:859-866.

20. Oshiro Y, Lee $Y$, King G. Mechanism of diabetic neprhopathy: role of protein kinase-c activation. Advanced Studies in Medicine. 2005;5:10-19.

21. Nishizuka Y. Intracelluler Signaling by Hydrolysis of Phospholipids and Activation of Protein Kinase C. Science. 1992;258:607-614.
22. Gutterman D. Vascular Dysfunction in Hyperglycemia: Is Protein Kinase C the Culprit? Circ Res. 2002;90:5-7.

23. Kao HH, Wu CJ, Won SJ, Shin JW, Liu HS, Su CL. Kinase Gene Expression and Subcellular Protein Expression Pattern of Protein Kinase $C$ Isoform in Curcumin-treated Human Hepatocelluler Carcinoma Hep 3B Cells. Plant Foods Hum Nutr. 2011;66:136-142.

24. Reddy S, Aggarwal BB. Curcumin is a non-competitive and selective inhibitor of phosphorylase kinase. FEBS Lett. 1994;94:19-22.

25. Jancinova V, Perecko T, Nosal R, Kostalova D, Bauerova K, Drabikova K. Decreased activity of neutrophils in the presence of diferuloylmethane (curcumin) involves protein kinase $\mathrm{C}$ inhibition. Eur J Pharmacol. 2009;612:161-166.

26. Menon VP, Sudheer AR. Antioxidant and inflammatory properties of curcumin. Adv Exp Med Biol. 2007;595;105-125. 